\title{
Nursing students' attitudes about their profession
}

\author{
Amela Salihović*, Jasmina Mahmutović, Suada Branković \\ Department of Nursing, Faculty of Health Studies, University of Sarajevo, Sarajevo, Bosnia and Herzegovina
}

\begin{abstract}
Introduction: Positive attitudes toward the nursing profession among nursing students improve the sustainability of the profession. Studying the attitudes of nursing students toward nursing is of great importance, as it can indicate their remaining in the profession. This study aimed to determine the attitudes of nursing students toward the nursing profession.

Methods: This was a cross-sectional, descriptive, analytical study. The research was conducted at the Faculty of Health Studies at the University of Sarajevo from May to June 2019. The study involved a convenience sample of 107 currently enrolled Bachelor of Nursing students from the $1^{\text {st }}$ to the $4^{\text {th }}$ (and final) year of full-time study and part-time students in the Baccalaureate of Nursing Care program at the University of Sarajevo. The students voluntarily and anonymously completed a questionnaire consisting of demographic information and the Nursing Image Questionnaire.

Results: Overall, 107 students participated in the research. Their mean age was 23 years old (standard deviation, 5 years). Spearman's correlation factor shows a statistically significant correlation between the scores and the mode of studying (full-time or part-time) (rho $=-0.200 *, p=0.039$ ) and whether respondents working in the profession or not (rho = $0.249 *, p=0.010)$.

Conclusion: The attitudes of future Bachelor of Nursing toward the nursing profession were very positive. Full-time students had more positive attitudes toward the profession, compared with part-time students, although the difference was not statistically significant.
\end{abstract}

Keywords: Attitudes; nursing care; nursing profession; nursing student

\section{INTRODUCTION}

The World Health Organization defined nursing as follows: "Nursing encompasses autonomous and collaborative care of individuals of all ages, families, groups and communities, sick, or well and in all settings. It includes the promotion of health, the prevention of illness, and the care of ill, disabled, and dying people" (1).

Nursing is an integral part of the healthcare delivery system, sharing responsibilities in collaboration with other allied health professions for the attainment of optimal health for all members of society (2). The study of nursing is becoming increasingly attractive, even for students who have attended nonmedical high schools, such as high schools/ gymnasiums, vocational, and economic high schools (3).

Today's nursing students' study in accordance with the European Directive and the Bologna Process, which enable the acquisition of comprehensive theoretical and practical competencies for performing complex tasks in healthcare and other related activities (4).

*Corresponding author: Amela Salihović, Faculty of Health

Studies, University of Sarajevo, Sarajevo, Bosnia and Herzegovina.

E-mail: amela.2901@hotmail.com

Submitted: 02 September 2021/Accepted: 15 November 2021

DOI: https://doi.org/10.17532/jhsci.2021.1480
The need for highly educated nurses in the healthcare system grows with the development of medical and nursing sciences that involve the application of increasingly complex forms of treatment, growing health needs of patients, application of new diagnostic procedures, and introduction of new nursing care processes and documentation. A significant problem in the education of nurses is the abandonment of studies. Research shows that, in Australia and Canada, up to $40 \%$ of enrolled students drop out of study. In the Netherlands, the dropout rate is $20-50 \%$. In Italy, the rate is up to $20 \%$ (5). Increasing attention is being paid to the education of nurses. Their education aims to prepare students for the responsible and professional performance of nursing work, stay in the profession, and influence the development of positive attitudes toward nursing (5).

In selecting a profession, an individual should have favorable views and attitudes toward it, if they are to adapt to the profession and maintain a productive working life. Having favorable views and attitudes toward the profession plays a significant role, not only in achieving good results but also in professional development (6). Positive attitudes toward the nursing profession among nursing students increase the sustainability of nursing students (7).

Studying the attitudes of nursing students and graduate nurses is of great importance, as it can indicate their 
remaining in the profession (8). Nursing students who think negatively about the profession may lose interest, which is an obstacle to academic performance and productivity (6).

Attitudes need to change. With a good level of education in society and quality work from nurses and nursing assistants, attitudes toward the nursing profession can improve. This process belongs to nurses and nursing assistants, who need to fight for more positive attitudes in society toward their profession (9). This research aimed at examining students' attitudes toward the nursing profession and examining whether there is a difference in attitudes between students in their $1^{\text {st }}$ year and $4^{\text {th }}$ year of study and whether there are differences between full- and part-time students.

\section{METHODS}

This was a cross-sectional, descriptive, analytical study conducted at the Faculty of Health Studies at the University of Sarajevo from May to June 2019. The study involved a convenience sample of 107 currently enrolled Bachelor of Nursing students from the $1^{\text {st }}$ to the $4^{\text {th }}$ year of full-time study and part-time students of the Baccalaureate Nursing Care program at the same university. The students voluntarily and anonymously completed a questionnaire consisting of demographic information and the Nursing Image Questionnaire (10), which includes 30 items that assess how an individual views the roles and tasks, values, and social stereotypes of nursing, along with the professionalism and performance of nurses. Cronbach alpha coefficient ranged from 0.75 to 0.80 . The respondents completed the questionnaire using a Likert-type scale from 1 to 5 , with 1 representing fully disagree and 5 representing fully agree. The total score of all ratings ranges from 30 to 150 points. In terms of attitude, a score $>60 \%$ ( 90 points) was counted as a good or positive attitude.

For statistical analysis, we used Statistical Package for the Social Sciences version 25.0 (IBM, Armonk, NY, USA), and for data processing, we used Microsoft Office 2019. Categorical variables are represented by frequency, as an absolute number, or incidence, as a percentage. The accepted level of significant difference was $p<0.05$. The Chi-squared test was used to compare the frequency and distribution of subjects within and between groups. If the expected values in contingency tables were $<5$ in more than $20 \%$ of the cells, a test modification was used using Fisher's exact test. The Mann-Whitney U test was used to compare nonparametric data between groups. The Spearman correlation factor was used to analyze the correlations between the examined variables and attitudes toward the nursing profession; correlation was calculated as $p$.

The Ethical board of the Faculty of Health Study approved the research. The purpose of the research was verbally explained to the examinees, and they received a written outline. They signed a consent form to participate in the research. Participation was voluntary and anonymous.

\section{RESULTS}

Overall, 107 students from the Faculty of Health Studies at the University of Sarajevo participated in the research. Their mean age was 23 years (standard deviation, 5 years).
There were $24(22.4 \%)$ male and $83(77.60 \%)$ female respondents. Of the 107 respondents, 28 (26.2\%) were $1^{\text {st }}$ year, $12(11.2 \%)$ were $2^{\text {nd }}$ year, $32(29.9 \%)$ were $3^{\text {rd }}$ year, and $35(32.7 \%)$ were $4^{\text {th }}$ year students. Sixty-eight $(63.6 \%)$ were full-time students, and $39(36.4 \%)$ were part-time students (Table 1).

Thirty-one (29\%) respondents were working in the nursing profession, of whom 22 (70.9\%) were part-time students. Male respondents had statistically significantly more professional experience, compared with female respondents $\left(\chi^{2}=8.031 ; p=0.0046\right)$.

In the analysis of attitudes, a questionnaire score of $>60 \%$ (90 points out of a maximum 150 points) indicated a positive attitude. All respondents' scores were above the cutoff median value of 117 points, with an interquartile range of $111-124$.

Fisher's exact test indicated a statistically significant difference in respondents' attitudes toward the nursing profession, based on whether they were working in the profession $(p=0.024)$. Respondents who were working in the profession had a negative attitude toward it. Fisher's exact test did not show a significant difference in attitude toward the profession based on gender $(p=0.904)$, year of study $(p=0.304)$, or mode of study $(p=0.058)$ (Table 2$)$.

Respondents had positive attitudes toward the nursing profession, based on the Mann-Whitney test. Full-time students had more positive attitudes, compared with parttime students, but the difference was not statistically significant $(p=0.041)$ (Table 3). Spearman's correlation factor showed a statistically significant correlation between the mode of studying (rho $=-0.200^{*}, p=0.039$ ) and whether respondents were working in the nursing profession or not (rho $=0.249^{*}, p=0.010$ ). We examined the correlations between certain variables and content areas of the questionnaire by which attitudes toward the nursing profession are rated. Spearman's correlation factor indicated the existence of a weak relationship between gender and nurses' attitudes toward professionalism; female respondents had slightly better attitudes than male respondents (rho $=0.223 ; p=0.021)$. A weak relationship was found in relation to the mode of studying, with full-time students having better attitudes toward the role of a nurse, compared with part-time students ( $\mathrm{rho}=0.235 ; p=0.015$ ).

In examining the correlations between the content areas of the questionnaire, Spearman's correlation factor showed

TABLE 1. Demographic characteristics of respondents

\begin{tabular}{lccl}
\hline Variable & $n$ & $\%$ & Age \\
\hline Gender & & & \\
$\quad$ Male & 24 & 22.4 & $24.4 \pm 5.9$ \\
Female & 83 & 77.6 & $22.6 \pm 5.9$ \\
$\quad$ Total & 107 & 100 & $23.0 \pm 5.1$ \\
Year of study & & & \\
$1^{\text {st }}$ & 28 & 26.2 & \\
$2^{\text {nd }}$ & 12 & 11.2 & \\
$3^{\text {rd }}$ & 32 & 29.9 & \\
$4^{\text {th }}$ & 35 & 32.7 & \\
Mode of studying & & & \\
$\quad$ Full-time & 68 & 63.6 & \\
Part-time & 39 & 36.4 & \\
\hline
\end{tabular}


a significant correlation between the attitudes toward the role of a nurse and the values of a nurse (rho $=0.406$; $p=0.001)$. Students with more positive attitudes toward the role of a nurse also showed fewer social stereotypes (rho $=0.460, p=0.001$ ), and more appreciated the professionalism of nurses (rho $=0.409 ; p<0.001$ ). Moreover, students who valued nurses more had fewer social stereotypes $($ rho $=0.423 ; p=0.001)($ Table 4$)$.

\section{DISCUSSION}

We reviewed scientific literature and previous research, finding a small number of studies that investigated the

TABLE 2. Comparison of respondents' attitudes toward the nursing profession

\begin{tabular}{|c|c|c|c|c|}
\hline \multirow[t]{3}{*}{ Variable } & \multicolumn{4}{|c|}{ Attitude toward the nursing profession } \\
\hline & \multicolumn{2}{|c|}{$\begin{array}{c}\text { Negative } \\
\text { attitude ( } \leq 60 \%)\end{array}$} & \multicolumn{2}{|c|}{$\begin{array}{c}\text { Positive } \\
\text { attitude (>60\% }\end{array}$} \\
\hline & $n$ & $\%$ & $n$ & $\%$ \\
\hline \multicolumn{5}{|l|}{ Gender } \\
\hline Total & 5 & 4.7 & 102 & 95.3 \\
\hline Male & 1 & 20 & 23 & 22.5 \\
\hline Female & 4 & 80 & 79 & 77.5 \\
\hline Fisher's exact test & \multicolumn{4}{|c|}{$p=0.904$} \\
\hline \multicolumn{5}{|l|}{ Year of study } \\
\hline $1^{\text {st }}$ & 0 & 0 & 28 & 27.5 \\
\hline $2^{\text {nd }}$ & 0 & 0 & 12 & 11.8 \\
\hline $3^{\text {rd }}$ & 3 & 60 & 29 & 28.4 \\
\hline $4^{\text {th }}$ & 2 & 40 & 33 & 32.4 \\
\hline Fisher's exact test & \multicolumn{4}{|c|}{$p=0.304$} \\
\hline \multicolumn{5}{|l|}{ Mode of studying } \\
\hline Full-time & 1 & 20 & 67 & 65.7 \\
\hline Part-time & 4 & 80 & 35 & 34.3 \\
\hline Fisher's exact test & \multicolumn{4}{|c|}{$p=0.058$} \\
\hline \multicolumn{5}{|c|}{ Working in the profession } \\
\hline Yes & 4 & 80 & 27 & 26.5 \\
\hline No & 1 & 20 & 75 & 73.5 \\
\hline Fisher's exact test & \multicolumn{4}{|c|}{$p=0.024^{*}$} \\
\hline
\end{tabular}

TABLE 3. Nursing image questionnaire scores assessing respondents attitudes toward the nursing profession

\begin{tabular}{lccccc}
\hline Mode of studying & Me & 25 per & 75 per & test & $p$ \\
\hline Full-time & 119 & 113 & 126 & Mann-Whitney & $0.041^{*}$ \\
Part-time & 115 & 109 & 120 & 1010.1 & \\
\hline${ }^{*} p<0.05$, Me, median; 25 per, $25^{\text {th }}$ percentile; 75 per, $75^{\text {th }}$ percentile
\end{tabular}

attitudes of nursing students toward the nursing profession in Bosnia and Herzegovina $(11,12)$.

Determining the attitudes of nursing students helps us understand how future nurses may perceive problems and processes in their profession and discover what qualities, they consider important, good, relevant, and appropriate (13). Our results show that respondents had positive attitudes toward the nursing profession. A 2020 study of 300 nursing students in Saudi Arabia also revealed positive attitudes toward nursing as a profession (14). Similar results have been obtained through research in Croatia $(5,15)$, Iraq (16), Saudi Arabia (17), Turkey (18), and Nepal (19).

When nursing students begin their studies, they have attitudes and beliefs regarding nursing that change as students are influenced by the educational program (5). The final year of academic study is a turning point for nursing students, most of whom are aware of the nurse's professional role (14).

However, our results do not show a statistically significant difference in attitudes toward the nursing profession related to the year of study $(p=0.304)$. Our results agree with those of the Saudi Arabian study referred to above, which showed no statistically significant difference in attitudes toward the nursing profession between students in their $1^{\text {st }}$ and $4^{\text {th }}$ years of study (14). However, Erkayiran et al. (2019) reported that students in their $4^{\text {th }}$ year of study had better attitudes toward the nursing profession than students in their $3^{\text {rd }}$ year of study (18), and a 2018 study from Croatia reported that $1^{\text {st }}$ year students had better attitudes, compared with $2^{\text {nd }}$ - and $3^{\text {rd }}$ year students (5).

Research shows that attitudes toward nursing change under the influence of nursing theory, science, and clinical experience (15). Our results show that respondents who were working in the profession had a negative attitude toward it, compared with respondents who had no experience in the profession. We also found that part-time students who worked in the profession had negative attitudes toward issues related to nursing practice (15).

We used Spearman's correlation factor to examine the content areas of the questionnaire to assess the attitudes of respondents toward the nursing profession. We found a weak relationship relating to the mode of study, with fulltime students having better attitudes toward the role of a nurse (rho $=0.235 ; p=0.015$ ), compared part-time students. Our results agree with those of Čukljek et al. (2015),

TABLE 4. Content areas of the questionnaire in relation to gender and mode of study

\begin{tabular}{lccccc}
\hline Variables & Role of a nurse & Values of a nurse & Social stereotypes & Professionalism & Characteristics of nurses \\
\hline Gender & 0.120 & 0.035 & 0.055 & $0.223^{*}$ & 0.115 \\
& 0.219 & 0.717 & 0.573 & 0.021 & 0.238 \\
Mode of studying & $-0.235^{*}$ & -0.121 & -0.143 & -0.138 & -0.045 \\
& 0.015 & 0.213 & 0.143 & 0.156 & 0.648 \\
The role of a nurse & 1.000 & $0.406^{* *}$ & $0.460^{\star *}$ & $0.409^{* *}$ & $0.240^{*}$ \\
& & 0.000 & 0.000 & 0.000 & 0.013 \\
Values of a nurse & $0.406^{* *}$ & 1.000 & $0.423^{* *}$ & $0.391^{* *}$ & 0.161 \\
& 0.000 & & 0.000 & 0.000 & 0.097 \\
Social stereotypes & $0.460^{* *}$ & $0.423^{\star *}$ & 1.000 & 0.002 & 0.085 \\
& 0.000 & 0.000 & & 1.000 & 0.382 \\
Professionalism & $0.409^{* *}$ & $0.391^{* *}$ & $0.300^{* *}$ & & $0.382^{* *}$ \\
& 0.000 & 0.000 & 0.002 & & 0.000 \\
\hline
\end{tabular}


who found that full-time students had more positive attitudes toward the role of a nurse compared with part-time students (15).

The proportion of respondents who disagreed with the statement nursing is a valued profession was $29.90 \%$. Our results agree with those Živanović et al. (2018), who assessed 60 students of the Faculty of Medicine in Foča, Bosnia and Herzegovina. They reported that students were dissatisfied with the position of the nursing profession in Bosnia and Herzegovina; $73.3 \%$ of respondents did not agree with the statement nursing is a valued profession (11).

Spearman's correlation factor indicated the existence of a weak relationship between gender and nurses' attitudes toward professionalism; female respondents had slightly better attitudes than male respondents. Furthermore, the results of the study show that male respondents had statistically significantly more professional experience compared to female respondents $\left(\chi^{2}=8.031 ; p=0.0046\right)$. The results of our research show that respondents who were working in the profession had a negative attitude toward it.

The results of our research show that students with more positive attitudes toward the role of a nurse also showed fewer social stereotypes ( $r h o=0.460, p=0.001$ ), and more appreciated the professionalism of nurses ( $r$ ho $=0.409$; $p<0.001)$. Nursing students need to be educated about a positive image toward their own profession. This can affect other attitudes in the nursing profession. If students have negative attitudes about their profession, it can result in a lack of interest which is an obstacle to academic success that affects student productivity.

We believe that working nurses and nursing students must lead the way in fostering better attitudes, and we recommend further, larger surveys of the attitudes of working nurses and nursing students. Research in nursing is important for the development of new theories and knowledge, without which there is no possibility of further developing nursing as an independent profession (13).

\section{CONCLUSION}

The attitudes of nursing students toward their profession were very positive. Nursing students who studied full-time had more positive attitudes toward the profession than those who studied part-time, but the difference was not statistically significant. The difference in attitudes toward nursing between $1^{\text {st }}$ year and $4^{\text {th }}$ year students were not statistically significant. Considering the difficulty of tasks performed by nurses at all levels of nursing care, it is recommended that future studies be conducted with larger samples of nurses who are employed in nursing care.

\section{STUDY LIMITATION}

This study sampled only small number respondents at a single institution of higher education.

\section{COMPETING INTERESTS}

The authors declare that there is no conflict of interest.

\section{REFERENCES}

1. Khatri A, Singh R. Knowledge and attitude towards nursing profession among male secondary level students. J Kathmandu Med Coll 2020;9(3):137-43. https://doi.org/10.3126/jkmc.v9i3.36412

2. Mohanasundari SK, Padmaja A, Jeet R, Raghu VA, Joseph J. A descriptive cross-sectional survey on attitude of nursing students towards chosen profession in India. Commun Public Health Nurs 2019;4(3):149-54.

3. Čukljek S, Smrekar M, Fićko SL, Konjevoda V. Razlike u percepciji sestrinstva između studenata sestrinstva i zaposlenih medicinskih sestara/differences. JAHS 2015;1(1):35-42.

https://doi.org/10.24141/1/1/1/3

4. Čukljek S, Karačić J, llić B. Stavovi studenata 3. Godine studija sestrinstva o sestrinstvu u hrvatskoj danas/attitudes of $3^{\text {rd }}$ year nursing students toward nursing in Croatia today. Polytech App Health Stud Zagreb 2011:2; 1-12

5. Kosier M, Čukljek S, Lučanin D. Stavovi studenata studija sestrinstva zdravstvenog veleučilišta o sestrinstvu u hrvatskoj/attitudes. J Appl Health Sci 2018;4(2):145-55. https://doi.org/10.24141/1/4/2/1

6. Fahmy S, Mayez A, Ali Refae E. Attitude of nursing students towards nursing profession at South Valley University. IJRDO J Health Sci Nurs 2020;5(6):19-34.

7. Bundasak T, Chaowieng KO, Thainkumsri K, Sittisongkram S, Jangasem N. Attitudes towards the nursing profession among nursing students of Boromarajonani College of Nursing, Phraphutthabat. Nurs Health Sci 2019;13(4):36-47.

8. Tawash E, Cowman S. Bahraini nursing students' attitudes: From student to nurse-a longitudinal research study. J Nurs Educ Pract 2015;5(12):79-87.

https://doi.org/10.5430/jnep.v5n12p79

9. Marinović I, Županić M. Stavovi studenata nezdravstvenih studija o sestrinskoj profesiji. [Hrvatski časopis za javno zdravstvo/attitudes of non-medical students towards the nursing profession]. Croat J Public Health 2017;13(51):84.

10. Čukljek $S$, Jureša V, Bile $C G$, Režek B. Changes in nursing students attitudes towards nursing during undergraduate study. Acta Clin Croat 2017;56(1):36-43 https://doi.org/10.20471/acc.2017.56.01.06

11. Živanović S, Šupić V, Kulić V. Stavovi studenata zdravstvene njege o ulozi medicinske sestre $u$ zdravstvenom timu/attitudes of health care students towards the role of a nurse in the health care team. Pons Med J 2018;15(2):75-8.

12. Jović $D$, Knežević $D$, Skrobić $M$, Matavulj A, Vučković J. Attitudes and opinions of health care students of medical faculty in Banja Luka about study program and nursing as a profession. Scr Med 2015;46(1):49-54 https://doi.org/10.5937/scrimed1501049j

13. Price B. Understanding attitudes and their effects on nursing practice. Nurs Stand 2015;30(15):50-7; quiz 60

https://doi.org/10.7748/ns.30.15.50.s51

14. Rabia SA. Nursing as a profession: Undergraduate female students' perception. TMR Integr Nurs 2020;4(2):65-72.

15. Čukljek S. Povezanost Prethodne Izobrazbe i Stavova Studenata Studija Sestrinstva o Sestrinstvu Kao Profesij/Relationship between Previous Education and Attitudes of Nursing Students towards Nursing as a Profession. Zagreb [Dissertation]. University of Zagreb, Faculty of Medicine; 2016.

16. Khaffaf SE. Mosul nursing students' attitudes toward the nursing profession. J Univ Shanghai Sci Technol 2020;22(12):145-53.

17. Jothishanmugam A, Mohammed A, Alla Al, Abdelsadig Ali MA. Perception of nursing students about nursing profession. Innov J Health Sci 2019;7(2):1-4.

18. Erkayiran O, Umit Senocak S, Demirkiran F. The role of nurses in professional perceptions of nursing students: A cross-sectional study. Int J Caring Sci 2019;12(1):199-209.

19. Paudel B, Koirala D. Perception of nursing students towards the profession and their suture career motive. IJSR 2019;10(1):309-12.

\section{RELATED ARTICLES PUBLISHED IN JHSCI}

1. Kvas A, Seljak J. The effects of education and training on self-esteem of nurse leaders. JHSCI. 2014;4(2):97-104. 